Available online on 15.08.2019 at http://ajprd.com
(C) 2013-19, publisher and licensee AJPRD, This is an Open Access article which permits unrestricted non-
commercial use, provided the original work is properly cited

Open ${ }_{\text {Access }}$

Research Article

\title{
PHYTOCEMICALS SCREENING AND CELL CYCLE ARREST ACTIVITY OF n-HEXANE EXTRACT OF Vernonia amygdalina Delile LEAVES AGAINST PANCREATIC CANCER CELL LINE
}

\author{
Fauzan M. L., Hasibuan P. A. Z*., Harahap U \\ Department of Pharmacology, Faculty of Pharmacy, Universitas Sumatera Utara, Medan, 20155, \\ Indonesia
}

\begin{abstract}
A B S T R A C T
Objective: This study aims to determined phytochemical compounds of simplex and $n$-hexane extract (nHE) of Vernonia amygdalina Delile Leaves and cell cycle arrest activity against PANC-1 cells.

Methods: The leaves of Vernonia amygdalina Delile were dried and extracted with $n$-hexane, followed by evaporation and freezedrying. Phytochemicals screening were analyzed with standard procedures. Cytotoxic activity was carried out using MTT assay method. PANC-1 cells were treated with different concentrations of $\mathrm{nHE}(500 \mathrm{ug} / \mathrm{mL}, 250 \mathrm{ug} / \mathrm{mL}, 125 \mathrm{ug} / \mathrm{mL}, 61.5 \mathrm{ug} / \mathrm{mL}$ and $31.25 \mathrm{ug} / \mathrm{mL}$ ) for 24 hours to obtained $\mathrm{IC}_{50}$ values. The cell cycle inhibition activity of nHE was carried out used flowcytometry method and apoptosis activity used double staining method.

Results: Then HE was identified contains steroids/triterpenoids. The $\mathrm{IC}_{50}$ was $114.80 \pm 1.21 \mathrm{ug} / \mathrm{mL}$. The nHE inhibited cell cycle PANC-1 on $\mathrm{M} 1$ phase $(67.39 \%)$ and it was induced apoptosis process on PANC-1 cells.

Conclusions: Our results suggest that extractsn-hexane of Vernonia amygdalina Delile Leaves had as cancer chemoprevention activities with inhibits cell cycle and spur apoptosis process on PANC-1 cells.
\end{abstract}

Keywords: Vernonia amygdalina Delile, Phytochemcial, Cytotoxic, Cell Cycle, apoptosis

A R T I C L E I N F 0: Received 06 May 2019; Review Completed 20 July 2019; Accepted 25 July 2019; Available online 15 August 2019

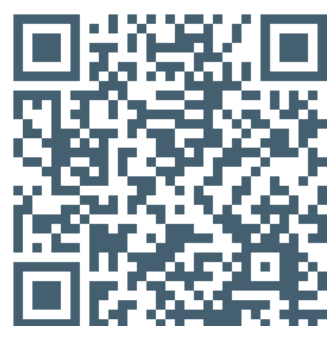

Cite this article as:

Fauzan M. L., Hasibuan P. A. Z., Harahap U, Phytocemicals Screening And Cell Cycle Arrest Activity Of $N$-Hexane Extract Of Vernonia Amygdalina Delile Leaves Against Pancreatic Cancer Cell Line, Asian Journal of Pharmaceutical Research and Development. 2019; 7(4):12-16, DOI: http://dx.doi.org/10.22270/ajprd.v7i4.533

*Address for Correspondence:

Hasibuan, P. A. Z, Department of Pharmacology, Faculty of Pharmacy, Universitas Sumatera Utara, Medan, 20155, Indonesia

\section{INTRODUCTION}

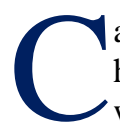
ancer was become a very scary disease because of high amount new and death cases occurred in the world $^{1}$. Pancreatic cancer was a type of disease that continued to develop in the world. It was a type of cancer that attack human's organ called pancreas ${ }^{2}$. Around 400 thousand new cases occurred in $2018^{3}$, with 331 thousand case leaded a death every year ${ }^{4}$. Lack of data about pancreatic cancer, the absence of specific symptoms, fast metastasis and resistance incidence of chemotherapeutics were the causes of high death cases by pancreatic cancer ${ }^{5-6}$.

Efforts to treated pancreatic cancer can be done with some method such as surgery, radiotherapy and chemotherapeutic.
Traditional medicine that was rich a Phytochemical compounds such as alkaloid, glycoside, polyphenol, saponin and steroid/ triterpenoid can used as alternative drug to pancreatic cancer ${ }^{7}$. Vernonia amygdalina Delile (VAD) was an Asteraceae plant, used as vegetable by west and center Africa people. Some research has done against VAD to find out the benefits in a health field between antimicrobial activity, antidiabetic activity and anticancer activity ${ }^{8-9}$. As a anticancer, VAD has been tested in vitro and in vivo, among others against nacofaring cancer cell, skin cancer cell ${ }^{10}$, prostate cancer cell ${ }^{11}$ and breast cancer cell ${ }^{12}$.

VAD activity for inhibit development some kind of cancer cells was a reason to do screening Phytochemical compounds 
in VAD. Phytochemical compounds in VAD can use as a drug cancer, especially for pancreatic cancer. As a potential pancreatic cancer drug, VAD must through some tests. Cytotoxic test, cell cycle inhibition and spur apoptosis into a test that can be done to determined the anticancer activity against pancreatic cancer cell.

\section{MATERIAL AND METHODS}

\section{Material}

All chemicals and reagents were procured from certified suppliers and were of the highest analytical standard. The pancreatic cancer cell (PANC-1) was obtained from Laboratory of Parasitology, Universities Gadjah Mada, Yogyakarta, Indonesia.

\section{Sampel Preparation and Extraction}

The leaves of Vernonia amygdalina Delile collected from garden of medical plants Faculty of Pharmacy, Universities Sumatera Utara, Medan, Indonesia. $1000 \mathrm{~g}$ of powdered were extracted by cold maceration with $n$-hexane $(3 \times 3 \mathrm{~d}$, $7,5 \mathrm{~L}$ ). The filtrate was collected and the evaporated under reduced pressure to give a viscous extract and then freezedried to give a dried extract ${ }^{13-14}$.

\section{Phytochemical Screening}

Phytochemical screening to determine alkaloids, glycosides, flavonoids, saponins, steroid/ triterpenoids and tannins were carried out according to standard procedures ${ }^{14}$.

\section{Cytotoxicity Test}

PANC-1 cell line was grown in DMEM medium containing $10 \%$ Fetal Bovine Serum (Gibco), 1\% penicillinstreptomycin (Gibco) and fungizone $0,5 \%$ (Gibco) in a flask with condition a humidified atmosphere $\left(5 \% \mathrm{CO}_{2}\right)$ at $37^{\circ} \mathrm{C}$. The inoculums seeded at $1 \times 10^{4}$ cells $/ \mathrm{mL}$ at an optimal volume of $0,1 \mathrm{~mL}$ per well. After $24 \mathrm{~h}$ incubated, the medium was discharged and treated by nHE. After $24 \mathrm{~h}$ incubated, the cells were incubated with $0,5 \mathrm{mg} / \mathrm{mL}$ MTT for $4 \mathrm{~h}$ at $37^{\circ} \mathrm{C}$. Viable cells reacted with MTT to produce purple formazan crystals. After $4 \mathrm{~h}$, SDS $10 \%$ as a stopper (Sigma) in $0,01 \mathrm{~N} \mathrm{HCl}$ (Merck) was added to dissolve the formazan crystals. The cells were incubated for $24 \mathrm{~h}$ in room temperature and protected from light. After incubated, the cells were shaken and absorbance was measured using microplate reader at $\lambda 595 \mathrm{~nm}$. The data which were absorbed from each well were converted to the percentage of viable cells ${ }^{13-17}$. The equation to determination viability of cells:

$$
\frac{\text { Abs of treatment }- \text { Abs of medium }}{\text { Abs of control cells-Abs of medium }} x 100 \%
$$

\section{Cell Cycle Inhibition Test}

PANC- 1 cells $\left(1 \times 10^{6}\right.$ cells/well) were seeded into 6-well plate and incubated for $24 \mathrm{~h}$. After that, the cells were treated nHE with $\mathrm{IC}_{50}$ concentration and incubated for $24 \mathrm{~h}$. The cells were collected in a conical tube using trypsin $0,025 \%$ and were washed with PBS, after that centrifugated at 2500 rpm for $5 \mathrm{~min}$. The sediment was collected and fixed in cold $70 \%$ ethanol in PBS at $4^{\circ} \mathrm{C}$ for $1 \mathrm{~h}$. After that, the cells were washed with cold PBS and resuspended the centrifuged at $3000 \mathrm{rpm}$ for $3 \mathrm{~min}$ and PI kit. The sediment was re suspended and incubated at $37^{\circ} \mathrm{C}$ for $30 \mathrm{~min}$. The samples were analyzed using FAC Scan flowctometry. The percentage of cells were calculated using Mod Fit Lt. 3.0.s ${ }^{13}$, $18,20$.

\section{Observation of Apoptosis}

PANC- 1 cells $\left(1 \times 10^{5}\right.$ cells/well, 24 - well plate) were plated on cover slips and incubated for $24 \mathrm{~h}$. After that, the cells were treated $\mathrm{nHE}$ with $\mathrm{IC}_{50}$ concentration and incubated for $24 \mathrm{~h}$. The medium was removed and washed using PBS. Cover slips were taken and put on glass slide before added with $10 \mu \mathrm{L}$ acridine orange-ethidium bromide and incubated for 15 minutes. Then were observed under the confocal microscope ${ }^{20}$.

\section{Statistical analysis}

All data were anelyzed with regression analysis using SPSS 22.

\section{RESULT AND DISCUSSION}

VAD activity as anticancer agent was reported. In this study was showed nHE can inhibit development of pancreatic cancer. nHE was obtained steroids/triterpenoids metabolite secondary. Phytochemicals content of simplex VAD and nHE can be seen on Table 1. Steroids/triterpenoids were indentified active as inhibited the development cell cancers 21-23. This was supported by cytotoxic nHE activity, the ability to inhibit the cell cycle and trigger apoptosis of PANC-1 cells.

Table 1 Phytochemicals content of simplex VAD and nHE

\begin{tabular}{|l|l|l|l|}
\hline No & Metabolite secondary & Simplex & nHE \\
\hline 1 & Alkaloids & - & - \\
\hline 2 & Flavonoid & + & - \\
\hline 3 & Glycoside & + & - \\
\hline 4 & Steroid/triterpenoid & + & + \\
\hline 5 & Saponin & + & - \\
\hline 6 & Tannin & + & - \\
\hline
\end{tabular}

Description: (+) shows that the simplicia VA and nHE contains secondary metabolite, (-) shows that the simplex VA and nHE not contain secondary metabolite. VA: Vernonia amygdalina, nHE: Extract $n$-hexane Vernonia amygdalina. Phytochemical compounds in simplex VA and nHE were different.

Cytotoxic effect of nHE against PANC-1 cells was carried out by MTT method ${ }^{13,15}$.PANC-1 cells were treated with some $\mathrm{nHE}$ concentrations $(500 \mathrm{ug} / \mathrm{mL}, 250 \mathrm{ug} / \mathrm{mL}, 125$ $\mathrm{ug} / \mathrm{mL}, 61.5 \mathrm{ug} / \mathrm{mL}$ and $31.25 \mathrm{ug} / \mathrm{mL}$ ). After that, $\mathrm{IC}_{50}$ were measured using a microplate reader at $595 \mathrm{~nm}$. The result of $\mathrm{IC}_{50}$ can be seen in the Table 2.nHE was showed have cytotoxic activity. $\mathrm{nHE}$ has an $\mathrm{IC}_{50} 114,80 \pm 1,21 \mathrm{ug} / \mathrm{mL}$ against PANC-1 cell. nHE was declared less active as anticancer because the $\mathrm{IC}_{50}<100 \mathrm{ug} / \mathrm{mL}$. However, $\mathrm{nHE}$ can still be developed as an anticancer because it has an $\mathrm{IC}_{50}$ value $<500 \mathrm{ug} / \mathrm{mL}(22)$.

Table $2 \mathrm{IC}_{50}(\mathrm{ug} / \mathrm{mL}) \mathrm{nHE}$ against PANC-1 cell

\begin{tabular}{|l|l|}
\hline Sample & $\mathrm{IC}_{50}(\mathrm{ug} / \mathrm{mL})$ \\
\hline $\mathrm{nHE}$ & $114.80 \pm 1.21$ \\
\hline
\end{tabular}

Description: $\mathrm{IC}_{50}$ was measured using MTT method, nHE: Extract $n$-hexane Vernonia amygdalina. 
nHE cytotoxic activity was also showed by changes in PANC-1 cells morphology and viability data after treatment. PANC-1 cells morphology and viability data can be seen in figure 1 and figure 2 . When viewed from figure $1, \mathrm{nHE}$ leaded death in PANC-1 cell. Cell morphology was changed

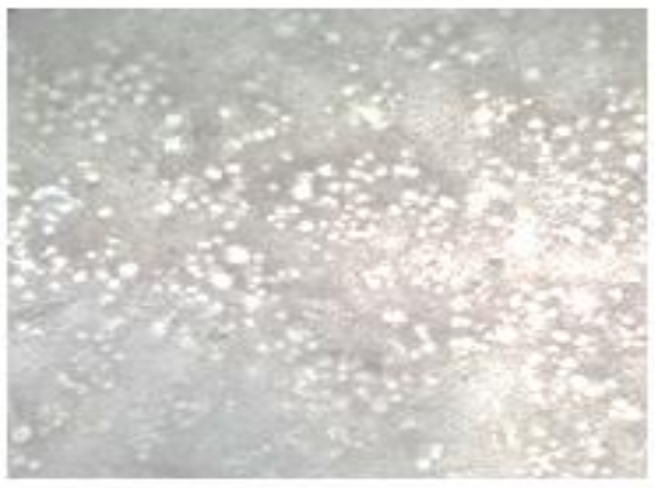

A. and having damaged ${ }^{25}$. If concentration of $\mathrm{nHE}$ was increased, then it will cause percentage of viability will decreased. Figure 2 showed, an increased in $\mathrm{nHE}$ concentration caused decreased percentage of viability at $85.66 \%, 83.33 \%, 48.33 \%, 17.66 \%$ and $3.57 \%$.

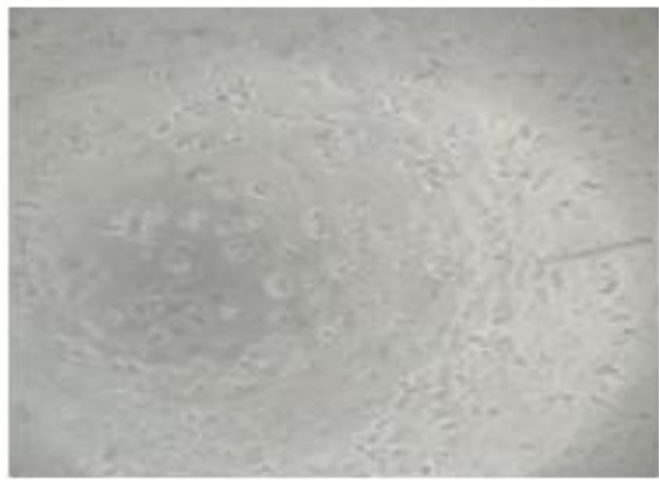

B

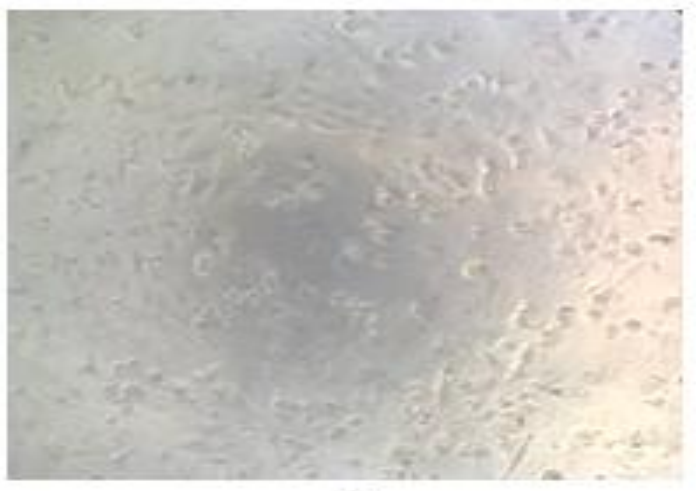

C

Figure 1: The cytotoxic effect of the sample on PANC-1 cell. The observation was performed under inverted microscope with 100x magnification.

The (blue arrows) showed normal cells and (black arrows) signs of morphological changes. A: nHE $500 \mathrm{ug} / \mathrm{mL}, \mathrm{B}$ : nHE $31.25 \mathrm{ug} / \mathrm{mL}, \mathrm{C}$ : Control Cell

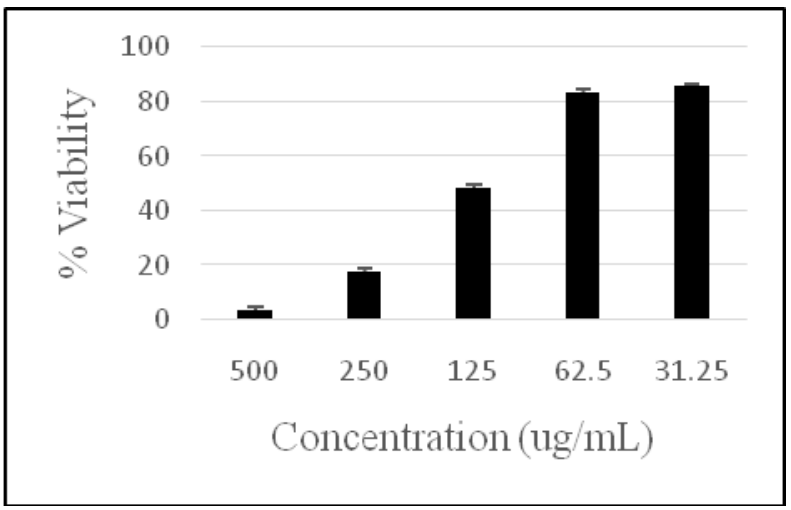

Figure 2: Percentage of viability Extract $n$-hexane Vernonia amgydalina $(500 \mathrm{ug} / \mathrm{mL}, 250 \mathrm{ug} / \mathrm{mL}, 125 \mathrm{ug} / \mathrm{mL}, 62.5 \mathrm{ug} / \mathrm{mL}$ and $31.25 \mathrm{ug} / \mathrm{mL})$ on PANC-1 cell.

As an anticancer, nHE must be able to inhibit the cell cycle. PANC-1 cell cycle inhibition activity of nHE was do flowcytometry method. PANC-1 cell was treated with nHE concentration $115 \mathrm{ug} / \mathrm{mL}$. Cell cycle inhibition effect can be seen in Figure 3. PANC-1 cell was treated with $\mathrm{nHE}$ concentration $115 \mathrm{ug} / \mathrm{mL}$. nHE leaded inhibition of PANC-1 cell cycle in M1 phase with cell accumulation at $67.39 \%$ and cell control at $17.32 \%$. This report was followed with decreasing cell cycle accumulation in G0-G1 phase, nHE at $19.36 \%$ and cell control at $50.51 \%$. This percentage was showed that the nHE can lead cell cycle inhibition in M1 phase. In the cell cycle analysis, nHE can decrease cell cycle accumulation in G0-G1 phase if compared with cell control. nHE can increased cell cycle accumulation in M1 phase if compared with cell control. M1-M5 phase was a phase who showed apoptosis accumulation of PANC-1 cell ${ }^{26-28}$. Based on the cell cycle inhibition tested, then the nHE can leaded apoptosis in PANC-1 cell.

Apoptosis can be defined as a process of programmed cell death and this process depend on biochemical mechanism of cell ${ }^{29}$. In this study, Figure 4 showed nHE was spurred apoptosis. Apoptosis PANC-1 cells was observation used confocale microscope. PANC-1 cell was treated with $\mathrm{nHE}$ concentration $115 \mathrm{ug} / \mathrm{mL}$. Before observation, thesample was first staining with $10 \mu \mathrm{L}$ acridine orange-ethidium bromide and incubated for 15 minutes. 


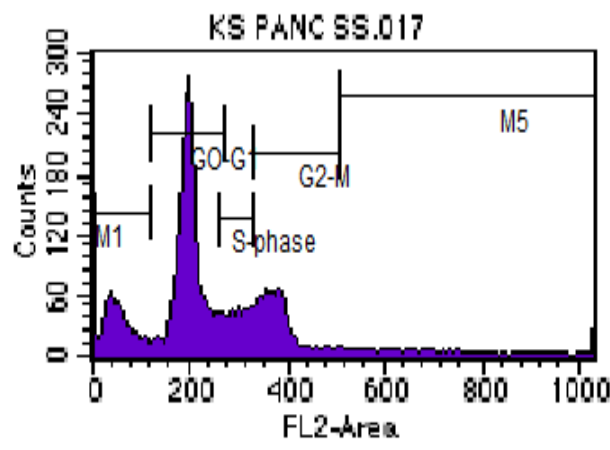

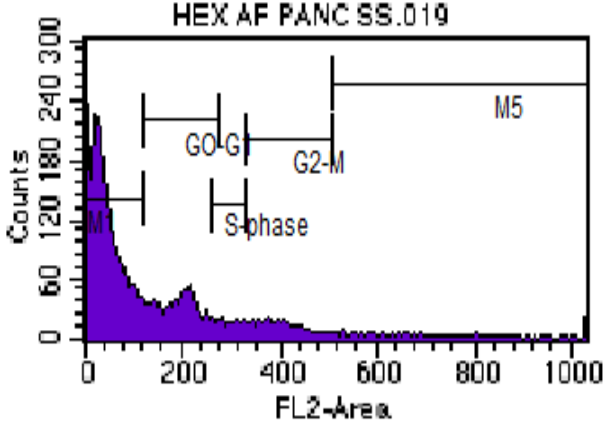

Figure 3: Cell cycle analysis using flowcitometry. PANC-1 cell was treated with $\mathrm{nHE} 115 \mathrm{ug} / \mathrm{mL}$ and stained using propidium iodide. A: Cell controls, B Extract $n$-hexane Vernonia amygdalina $115 \mathrm{ug} / \mathrm{mL}$.

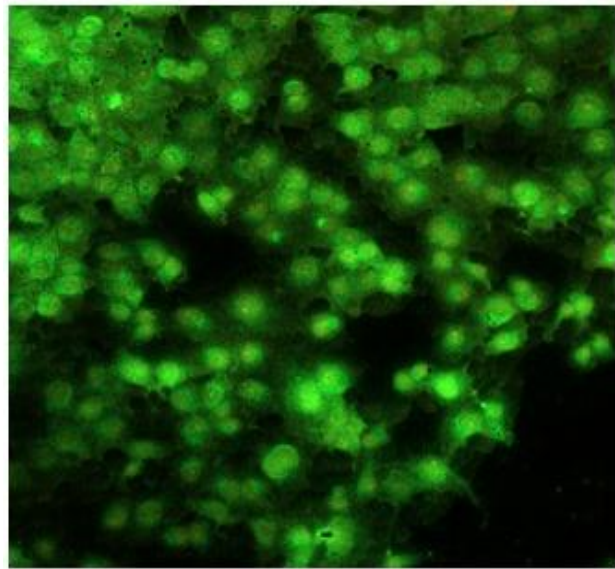

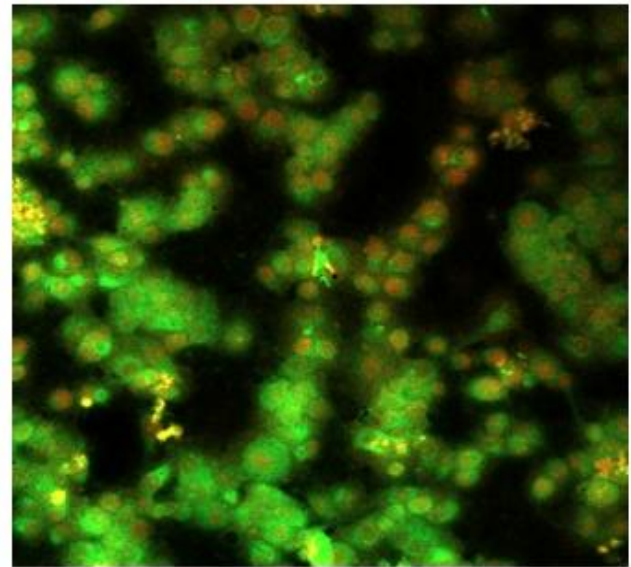

Figure 4: Observation of apoptosis in fluorescence microscope with 40x magnification and $3 \mathrm{x}$ zoom out. A: Control cell, B: Extract $n$-Hexane Vernonia amygdalina with concentration $115 \mathrm{ug} / \mathrm{mL}$.

Apoptosis testing was done used double staining method. Green fluorescent cells show living cells, while red fluorescent cells show dead cells (30). On the control cells, green fluorescent can be seen because it only absorbs acridine orange. Ethidium bromide cannot enter to the cell control because cell integrity is still good. In Figure 4B showed, cells with treatment $150 \mathrm{ug} / \mathrm{mL} \mathrm{nHE}$ was spurred apoptosis. Red fluorescent in the cells was showed the cells loss of membrane permeability and leaded ethidium bromide can enter the cells. It was as an indicator that cells death ${ }^{31}$.

\section{CONCLUSION}

The activity shown by nHE in inhibiting the development of PANC-1 cells was good. There needs to be futher exploration of the nHE mechanism as an anticancer pancreas. Exploring of the effect $\mathrm{nHE}$ in inhibiting gene expression associated with the cell cycle and apoptosis like p53, cyclin $\mathrm{D}, \mathrm{PI} 3 \mathrm{~K} / \mathrm{Akt} / \mathrm{mTOR}$ is an interesting thing to do. By examining gene expression, it will show the nHE mechanism of action.

\section{ACKNOWLEDGEMENT}

This research was funding by Ministry of Research Technology and Higher Education through "Hibah Penelitian Tesis Magister 2018".

\section{REFERENCES}

1. World Health Organization, International Agency for Research on Cancer, GLOBOCAN 2012: Estimated Cancer Incidence, Mortality and Prevalence World Wide in 2012

2. Darmawan G and Simadibrata M. Pancreatic Cancer: Review Of Etiology, Clinical Features, Diagnostic Prosedures, Treathment And Mesothelin Role.The Indonesian Journal of Gastroenterology Hepatology and Digestive Endoscopy. 2011; 4(1):44.

3. Bray F, Ferlay J, Soerjomataram I, Siegel RL, Torre LA, Jemal A. Global Cancer Statistics 2018: GLOBOCAN Estimates of Incidence and Mortality Worldwide for 36 Cancers in 185 Countries. A Cancer Journal of Clinicians. 2018; 68(6): 1.

4. FerlayJ, Soerjomataram I, Dikshit R, Eser S, Mathers C, Rebelo M, Parkin DM, Forman D, Bray F. Cancer Incidence and Mortality Worldwide: Sources, Methods and Major Patterns in GLOBOCAN 2012. International Journal of Cancer. 2015; 136: E364-E365.

5. Oktarina AB, Rasyad SB, Safyudin. Karakteristik Penderita Kanker Pankreas di Instalasi Rawat Inap RSUP Dr. Mohammad Husein Palembang Tahun 2009 - 2013. MKS. 2015; 47(1): 26-27.

6. Conze D, Weiss L, Regen PS, Bhushan A, Weaver D, Johnson P, Rincon M. Autocrine Production of Interleukin 6 Causes Multi Drug Resistance In Breast Cancer Cells. Cancer Research. 2001; 61(24): 8851.

7. Al-Sheddi ES, Farshori NN, Al-Oqail MM, MusarratJ, AAlKhedhairy AA, Siddiqui MA, Asian pacific Journal of Cancer Prevention. 2015; 16(8):3383

8. Ijeh I I and Ejike CECC. Current perspectives on the medicinal potentials of Vernonia amygdalina Del.J Med Plant Res. 2011; 5(7): 1051-1061.

9. Oyedeji KO, Bolarinwa AF, Akintola AM. Effect of Methanolic Extract of Vernonia amygdalina on Reproductive Parameters In Male Albino Rats. Journal of Dental and Medical Sciences. 2013; 3(5):64. 
10. Farombi EO and Owoeye O. Antioxidative and Chemopreventive Properties of Vernonia amygdalina and Garcinia biflavonoid. Int $\mathbf{J}$ Environ Res Public Health. 2011; 8:2538.

11. Johnson W, Tchounwou PB, Yedjou CG. Therapeutic Mechanisms of Vernonia amygdalina Delile in the Treatment of Prostate Cancer. Molecules. 2017; 22:1594.

12. Wong FC, Woo CC, Hsu A, Tan BKH. The Anti-Cancer Activities of Vernonia amygdalina Extract in Human Breast Cancer Cell Lines Are Mediated through Caspase-Dependent and p53-Independent Pathways. Plos One. 2013; 8(10):1.

13. Satria D, Furqan M, Hadisahputra S, Rosidah. Combinational Effects of Ethylacetate Extract of Picria fel-terrae Lour and Doxorubicin on T47D Breast Cancer Cells. J Pharm Pharm Sci. 2015; 7:74.

14. Satria D, Silalahi J, Haro G, Ilyas S, Hasibuan PAG. Chemical Analysis and Cytotoxic Activity of N-Hexane Fraction of Zanthoxylum acanthopodium DC. Fruits. Rasayan J Chem. 2019; 12(2):803-808.

15. Harahap U, Hasibuan PAZ, Sitorus P, Arfian N, Satria D. Antimigration Activity of an Ethylacetate Fraction of Zanthoxylum acanthopodium DC. Fruits in 4T1 Breast Cancer Cells. Asian Pacific Journal of Cancer Prevention. 2018; 19(2):565-589.

16. Harbone JB, Phytochemical Method, Chapman and Hall Ltd, London; 1984:151-152.

17. Hasibuan PAZ, Jessy C, Satria D. Combination Effect of Ethylacetate Extracts of Plectranthus ambonicius (Lour.) Spreng with Doxorubicin against T47D Breast Cancer Stem Cells. J Pharm Pharm Sci. 2015; 7: 158.

18. Anggraini R, Hadisaputra S, Silalahi J. Combinational Effects of Ethylacetate Extracts of Zanthoxylum acanthopodium DC. With Doxorubicin on T47D Breast Cancer Cells. International Journal of Pharm Tech Research. 2014; 6(7): 2034.

19. Nurrochmad A, Lukitaningsih E, Meiyanto E. Anticancer Activity of Ruden Tuber (Thyphonium flagelliforme (Lodd.)) Blume On Human Breast Cancer T47D Cells. International Journal of Phytomedicine. $2011 ; 3: 140$.

20. Elmore, S. Apoptosis: A Riview of Programmed Cell Death. Toxicol Pathol, 2007; 35(4):495-516.

21. Yeap SK, Ho WY, Beh BK, Liang WS, Ky H, Yousr AHN, Alitheen NB. Vernonia amygdalina, an Ethnoveterinary and Ethnomedical Used Green Vegetable with Multiple Bioactivities. J Med Plant Res. 2010; 4(25):2796.
22. Illian DN, Basyuni D, Wati R, Hasibuan PAZ. Polyisoprenoids from Avicennia marina and Avicennia lanata Inhibit WiDr Cells Proliferation.Phcog Mag. 2018; 14(58):516-518.

23. Sari DP, Basyuni M, Hasibuan PAZ, Wati R. The Inhibition of Polyisoprenoids from Nypa fruticans Leaves on Cyclooxygenase 2 Expression of WiDr Colon Cancer Cells. Asian J Pharm Clin Res. 2018; 11(8):156.

24. Chekuri S, Panjala S, Anupalli RR. Cytotoxic activity of Acalypha indica L. Hexane Extract on Breast Cancer Cell Lines (MCF-7). The Journal of Phytopharmacology. 2017; 6(5):266-267.

25. Setyowati EP, Pratiwi SUT, Purwatiningsih, I. Purwantini. In-vitro Cytotoxicity and Apoptosis Mechanism of Ethyl Acetate Extract from Trichoderma reesei strain TV221 Associated with Marine Sponge: Stylissa flabelliformis. Journal of Applied Pharmaceutical Science. 2018; 8(09):153.

26. Mutiah R, Indradmojo C, Dwi HH, Griana TP, Listyana A, Ramdhani R. Induction of Apoptosis and Phase-Cell Cycle Inhibiton of G0-G1, S, G2-M of T47D Breast Cancer Cells on Treatment with Ethyl Acetate Fraction of Jack Fruit Parasite Leaves (Macrosolen cochinensis). Journal of Applied Pharmaceutical Science. 2017; 7(10):141.

27. R. Mutiah, A. Listiyana, A, Suryadinata, R. Annisa, A. Hakim, W. Anggraini, R. Susilowati. Acitivity of Inhibit the Cell Cycle and Induct Apoptosis in HeLa Cancer Cell with Combination of Sabrang Onion (Eluetherine palmifolia (L.) Merr) and Starfruit Mistletoe (Macrosolen cochinehinensis (Lour.) Tiegh). Journal of Applied Pharmaceutical Science. 2018; 8(10):124.

28. Satria D, Silalahi J, Haro G, Syafruddin. I, HasibuanPAZ. Cell Cycle Inhibition of Ethylacetate Fraction of Zanthoxylum Acanthopodium DC. Fruit against T47D Cells. Macedonian Journal of Medical Sciences. 2019; 7(5): 178 .

29. Kennedy J, J. R. Marchesi, A. D. W. Dobson. Metagenomic Approaches to Exploit the Biotechnological Potential of the Microbial Consortia of Marine Sponges. Applied Microbiology and Biotechnology. 2007; 75(1): 11-20.

30. Fink SL, Cookson BT. Apoptosis, Pryptosis and Necrosis: Mechanistic Description of Dead and Dying Eukaryotic Cells. Infect Immun. 2005; 73(4):495-516.

31. Dogan SM, Ercetin AP, Altun Z, DursunD, Aktas S. Gene Expression Characteristic of Breast Cancer Stem Cell. JBUON. 2015; 20:13041313. 